\title{
A COMPARISON BETWEEN THE BAIN AND MAGILL ANAESTHETIC SYSTEMS DURING SPONTANEOUS BREATHING
}

\section{M.J. UNGERER}

A CO-AXIAL Version of the Mapleson D anaesthetic system was described by Bain and Spoerel in 1972.' The main feature of the Bain circuit was the incorporation of the fresh gas inflow tubing inside the exhalation limb. Their results suggested that a fresh gas inflow of 70 $\mathrm{ml} / \mathrm{kg}$ would be adequate to maintain normocarbia in the majority of patients during controlled ventilation, provided that the minute volume is high enough. ${ }^{2}$ These results have been confirmed by Henville and Adams. ${ }^{3}$

It has also been claimed that the same fresh gas flow which will maintain normocarbia in patients on controlled ventilation will also maintain a normal $\mathrm{Pa}_{\mathrm{CO}_{2}}$ in patients breathing spontaneously if respiratory depression is avoided ${ }^{4}$ However, the Mapleson D system has been shown to be much less efficient than the Mapleson A (Magill) system during spontaneous breathing. A fresh gas flow exceeding twice the patient's minute volume has been suggested. ${ }^{5}$

This study was devised in an effort to further investigate flow requirements by comparing the efficiency of the Bain system with that of the Magill system in conscious subjects breathing spontaneously under identical conditions.

\section{METHODS}

The experiment was performed in ten healthy conscious volunteers. A conventional Magill attachment was compared with a Bain system as modified by Henville and Adams. ${ }^{6}$ This modification incorporates an expiratory valve and reservoir bag attached by an adaptor to the outer tube of the Bain system at the end distant from the patient.

Air was supplied from cylinders through precalibrated rotameters. The seated subject, with a nose-clip applied, breathed air through a rubber mouthpiece from one of the systems. Both systems were evaluated at the same session.

Expired minute volume was measured continuously with a pre-calibrated direct-reading

Department of Anaesthesiology, University of the Orange Free State, Bloemfontein 9301, South Africa.

Canad. Anaesth. Soc. J., vol. 25, no. 2, March 1978
Wright electronic spirometer. Gas was taken intermittently from a point close to the patient's mouth and analyzed for carbon dioxide concentration on an infra-red analyzer (Godart Capnograph) and the signals were recorded. To minimize the effects of the withdrawn gas on the behaviour of the systems, samples were not taken continuously, but only for a short time during each observation period. Rate of withdrawal of gas was $200 \mathrm{ml} /$ minute.

Initially, the flow rate was set at $150 \mathrm{ml} / \mathrm{kg}$ for several minutes to establish a baseline. Thereafter, the flow rate was reduced stepwise by 10 $\mathrm{ml} / \mathrm{kg}$ at four-minute intervals until the fresh gas flow was reduced to $50 \mathrm{ml} / \mathrm{kg}$. Observations were taken at the end of each four-minute period.

All subjects acted as their own controls and the results were analyzed statistically using a paired Student's t-test.

\section{RESULTS}

The appearance of carbon dioxide in the inspired gas was taken as evidence of rebreathing. No rebreathing was evident with the Magill system until the flow was reduced below approximately $80 \mathrm{ml} / \mathrm{kg}$. However, rebreathing could be demonstrated with the Bain system at all the fresh gas flow rates used in this study. Recordings of the carbon dioxide concentration in one subject is shown in Figure 1.

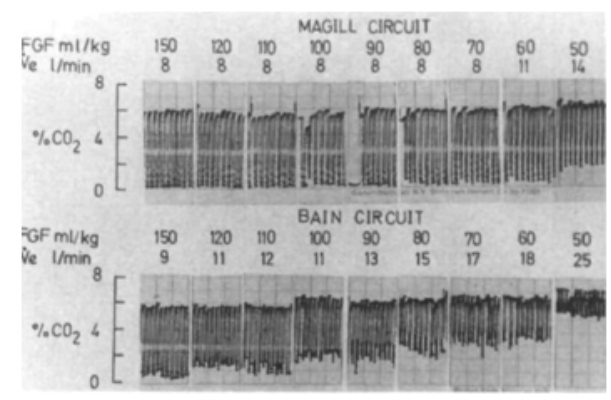

Figure 1 Recordings of carbon dioxide concentration in one subject:

$\mathrm{FGF}=$ fresh gas flow rate in $\mathrm{ml} / \mathrm{kg}$

$\dot{\mathrm{V}}_{\mathrm{E}}=$ expired minute volume in litres/minute. 
TABLE I

Mean Expired Minute Volumes (Litres/Minute) in Ten Subjects Breathing air Through a Bain or a Magill System. P Values (Paired T-Test) Refer to Mean Values

\begin{tabular}{|c|c|c|c|c|c|}
\hline \multirow{2}{*}{$\begin{array}{c}\text { Fresh gas flow } \\
\mathrm{ml} / \mathrm{kg}\end{array}$} & \multicolumn{2}{|c|}{ Bain } & \multicolumn{2}{|c|}{ Magill } & \multirow[b]{2}{*}{$\mathbf{P}$} \\
\hline & Mean & SD & Mean & SD & \\
\hline 150 & 9.44 & 2.82 & 8.98 & 2.94 & n.s. \\
\hline 130 & 11.42 & 2.75 & 8.60 & 2.41 & $<0.025$ \\
\hline 110 & 11.94 & 2.44 & 8.78 & 2.27 & $<0.01$ \\
\hline 100 & 13.61 & 2.32 & 8.89 & 2.43 & $<0.005$ \\
\hline 90 & 14.8 & 2.96 & 9.10 & 2.40 & $<0.0005$ \\
\hline 80 & 16.55 & 3.99 & 9.50 & 2.60 & $<0.000 s$ \\
\hline 70 & 18.50 & 3.69 & 10.45 & 2.74 & $<0.0005$ \\
\hline 60 & 21.40 & 4.40 & 12.80 & 3.43 & $<0.0005$ \\
\hline 50 & 24.33 & 4.18 & 15.88 & 6.11 & $<0.01$ \\
\hline
\end{tabular}

TABLE II

Mean End-Tidal Carbon Dioxide Concentrations in Ten Subjects Breathing Air Through a Bain or a Magill System. P Values (Paired T-Test) Refer to Mean Values

\begin{tabular}{ccccccc}
\hline \hline & \multicolumn{3}{c}{ Bain } & & \multicolumn{2}{c}{ Magill } \\
\cline { 2 - 3 } $\begin{array}{c}\text { Fresh gas flow } \\
\text { ml/kg }\end{array}$ & Mean & SD & & Mean & SD & P \\
\hline 150 & 6.48 & 0.55 & & 5.92 & 0.67 & $<0.025$ \\
130 & 6.61 & 0.54 & & 5.99 & 0.68 & $<0.01$ \\
110 & 6.80 & 0.61 & 5.93 & 0.78 & $<0.0025$ \\
100 & 6.82 & 0.53 & 6.03 & 0.88 & $<0.0025$ \\
90 & 6.81 & 0.58 & 6.09 & 0.76 & $<0.0025$ \\
80 & 6.92 & 0.62 & 6.09 & 0.69 & $<0.0005$ \\
90 & 7.21 & 0.68 & 6.31 & 0.63 & $<0.0005$ \\
60 & 7.45 & 0.72 & 6.42 & 0.59 & $<0.0005$ \\
50 & 7.72 & 0.88 & 6.67 & 0.66 & $<0.025$ \\
\hline
\end{tabular}

The mean expired minute volumes of all subjects are shown in Table 1 . The larger minute volumes when breathing through a Bain system as compared with the Magill circuit were highly significant at all flow rates except at $150 \mathrm{ml} / \mathrm{kg}$. Mean end-tidal carbon dioxide concentrations of the subjects are shown in Table II. These values were significantly higher when breathing through a Bain circuit at all gas flow rates.

The expired minute volumes when no rebreathing took place were higher than the accepted normal values for subjects at sea level. However, this study was conducted at an altitude of 1,422 metres and the values are within normal limits for subjects at high altitudes.?

\section{Discussion}

The appearance of carbon dioxide in the inspired air, a rise in end-tidal carbon dioxide concentration and an increase in expired minute volume are indices that rebreathing is occurring.
This investigation supports the view that the Magill system is highly efficient during spontaneous breathing. With this system, rebreathing became apparent only at a fresh gas flow rate of approximately $80 \mathrm{ml} / \mathrm{kg}$. These results confirm the findings of other reports. ${ }^{8,9}$

In comparison, the Bain system is less efficient with regard to fresh gas economics during spontaneous breathing. Rebreathing was evident at all flow rates used in this study $(150 \mathrm{ml} / \mathrm{kg}$ and below). Mean expired minute volume was 4.9 per cent higher than with the Magill system at a fiow rate of $150 \mathrm{ml} / \mathrm{kg}$ and increased progressively to 40 per cent higher at a flow rate of $60 \mathrm{ml} / \mathrm{kg}$. Mean end-tidal carbon dioxide concentration increased from 6.48 per cent to 7.45 per cent with the Bain circuit as compared to an increase from 5.92 per cent to 6.42 per cent with the Magill circuit during the same period.

Since the carbon dioxide production is lower in the anaesthetized patient it may be assumed that lower fresh gas flow would be required to prevent 
rebreathing during anaesthesia. However, it was shown in a recent case report that considerable rebreathing took place with the Bain circuit in an anaesthetized patient breathing spontaneously. A much higher minute volume than was the case with the Magill circuit was necessary to maintain an acceptable $\mathrm{Pa}_{\mathrm{CO}_{2}}$ level. ${ }^{10}$

Nevertheless, the Bain circuit has been safely used in many patients breathing spontaneously. ${ }^{1,4}$ This may be explained by the fact that the response to carbon dioxide remains adequate during anaesthesia and that carbon dioxide may be kept within acceptable limits through active hyperventilation. The question whether the additional effort and work of breathing demanded from the patient is deleterious remains to be answered. The conventional view has always been that minimal rebreathing should be permitted in spontaneously breathing patients. However, it has recently been suggested that the administration of a low concentration of carbon dioxide may be innocuous during spontaneous breathing under anaesthesia and may even be useful to support ventilation and circulation and may reduce cerebrovascular vasoconstriction in hypertensive patients. "

Other studies ${ }^{2,3}$ have demonstrated that the Bain circuit may be used safely and economically during controlled ventilation. Although clinical experience has shown it to be safe in many patients breathing spontaneously, in view of the results of this study its universal use in spontaneously breathing patients, especially with low fresh gas flow rates, cannot be commended. In certain situations such as increased intracranial pressure and chronic lung disease, its use may be regarded as hazardous during spontaneous breathing.

\section{SUMMARY}

The efficiency of the Bain system has been compared with that of the Magill system in ten conscious subjects breathing spontaneously. Air was supplied at fresh flow rates of $150 \mathrm{ml} / \mathrm{kg}$ and decreased stepwise at four-minute intervals until a flow of $50 \mathrm{ml} / \mathrm{kg}$ was attained. Expired minute volume and end-tidal carbon dioxide concentrations were measured.

No rebreathing could be demonstrated with the Magill system at flow rates above approximately $70 \mathrm{ml} / \mathrm{kg}$. In contrast, rebreathing was evident at all flow rates with the Bain system.
It is concluded that acceptable carbon dioxide levels during spontaneous breathing with the Bain circuit can only be maintained by considerable active hyperventilation when using flow rates of $150 \mathrm{ml} / \mathrm{kg}$ and less.

\section{RÉSUMÉ}

Les systèmes de Bain et de Magill ont été comparés chez dix sujets conscients en respiration spontanée. Les débits de gaz frais de $150 \mathrm{ml} /$ $\mathrm{kg} /$ minutes étaient diminués en palier aux quatre minutes, jusqu'à un niveau de $50 \mathrm{ml} / \mathrm{kg}$. On mesurait le volume expiré-minute ainsi que la $\mathrm{CO}_{2}$ de fin d'expiration.

On n'a pu mettre en évidence de rebreathing avec le système de Magill lorsque les débits de gaz frais étaient au-dessus de $70 \mathrm{ml} / \mathrm{kg} /$ minute. Par contre, un rebreathing était évident à tous les débits administrés avec le système de Bain.

Nous concluons qu'avec des débits de gaz frais inférieurs à $150 \mathrm{ml} / \mathrm{kg}$ avec un circuit de Bain, des taux acceptables de $\mathrm{PCO}_{2}$ ne peuvent être obtenus qu'au coût d'une hyperventilation active et considérable.

\section{REFERENCES}

I. Bain, J.A. \& Spoerel, W.E. A streamlined anaesthetic system. Can. Anaesth. Soc. J. 19: 426 (1972).

2. BAIN, J.A. and SPOEREL, W.E. Flow requirements for a modified Mapleson D system during controlled ventilation. Can. Anaesth. Soc. J. 20:629 (1973).

3. Henville, J.D. \& Adams, A.P. The Bain anaesthetic system. Anaesthesia 31:247 (1976).

4. Spoerel, W.E. \& Bain, J.A. Correspondence. Can. Anaesth. Soc. J. 22:626(1975).

5. SYKes, M.K. Rebreathing circuits. Brit. J. Anaesth. 40:666(1968).

6. Henville, J.D. \& ADAms, A.P. A co-axial breathing circuit and scavenging value. Anaesthesia $31: 257$ (1976).

7. Goldman, H.I., Zw1, S., Levin, N.W., Rubenstein, A.H., Stagles, D.P., van As, A.W.W., \& ELLIOTT, G.A. Normal values for arterial blood $\mathrm{pH}$, carbon dioxide tension and content, at an altitude of 5,750 feet. South Afr. Med. J.4: 97 (1967),

8. KAIN, M.L. \& NUNN, J.F. Fresh gas economics of the Magill circuit. Anesthesiology 29:964 (1968).

9. Norman, J., Adams, A.P., \& Sykes, M.K. Rebreathing with the Magill attachment. Anaesthesia 23: 75 (1968).

10. MANSWELL, W.H. Spontaneous breathing with the Bain circuit at low flow rates: a case report. Can. Anaesth. Soc. J. 23:432 (1976).

11. Dobkin, A.B., Byles, P.H., Africa, B.F., \& LEVY, A.A. A comparison of eleven general anaesthetics administered with 7.5 per cent carbon dioxide during spontaneous breathing. Can. Anaesth. Soc. J. 23:408 (1976). 